\title{
Woord Vooraf
}

Ek glo dat Immanuel Kant se Grundlegung zur Metaphysik der Sitten reeds in die tale van al die beskaafde lande van die wêreld verskyn het. Ek bedoel daarmee die lande wat reeds begin het om ' $n$ tradisie van nadenke, veral nadenke oor die lewe van die mens en sy betekenis op te bou. Kant se werkie, wat in 1785 verskyn het, is in taal, uitdrukkingswyse, sommige voorbeelde, wêreldbeskouing en so meer, in 'n mate verouderd. Tog bly die trefkrag van die etiese stellings vandag nog net so skerp en vars soos toe dit verskyn het.

Hiermee word 'n poging aangewend om die Grundlegung in Afrikaans beskikbaar te stel. Die bedoeling daarmee is in die eerste plek om studente met gevorderde belangstelling in Kant te help. In die tweede plek is Kant se taal - en dan veral sy berugte bladsylange sinne - nie so toeganklik vir persone wat Duits nie goed magtig is nie. Juis aan die taalprobleem moet ons enkele opmerkings wy. Ek het probeer om Kant leesbaar te vertaal en tog iets van sy taal en styl te behou. Of dit 'n geslaagde poging is, is twyfelagtig. Daar is egter enkele terme wat ek as voorbeeld wil noem om die wyse van vertaling ' $n$ bietjie duideliker te maak: Letterlike vertaling is in elk geval swak vertaling. Daar is egter ' $n$ paar woorde, waarvan die Duitse Objekt en Sinn goeie voorbeelde is. Objekt kan met 'voorwerp' of 'doel' en Sinn, veral sinnlich, kan met 'sinlik' of 'sintuiglik' vertaal word. In sulke gevalle het ek vertaal met Afrikaanse terme wat die betekenis van die teks die beste na vore bring. Dikwels was dit nodig om hele sinne te omvorm.

Ek maak van min afkortings gebruik. Die wat wel gebruik word, is internasionaal bekend of is genoodsaak deur die beskikbare skryftekens:

1. Die standaarduitgawe van Kant se werke, wat internasionaal aanvaar word, is die uitgawe van die Königliche Preuszische 
Akademie der Wissenschaften, wat van 1910 af uitgegee is. Dit het gebruik geword om enige teksuitgawe of vertaling van Kant se werke te vergesel met ' $n$ bladsyverwysing na die Akademieuitgawe, om studente se verwysing na die oorspronklike te vergemaklik. In hierdie teks verskyn die verwysing as 'n syfer in vierkantige hakies (byvoorbeeld [404]).

2. Hier en daar plaas Kant 'n opskrif bokant 'n gedeelte wat hy geskrywe het. Dit word in gewone druk weergegee, of in kursief in die enkele gevalle waar Kant dit doen. By $\mathrm{H} J$ Paton het ek egter die metode afgekyk om dikwels van paragraafopskrifte gebruik te maak, omdat dit die leser help om die draad van die redenasie te volg. Hierdie opskrifte wat van my kom, staan in krulhakies (byvoorbeeld \{Die rol van die rede\}). Alleen die opskrifte in kruihakies word in die inhoudsopgawe weerspieël.

3. Met 'n hekkieteken plus 'n syfer (byvoorbeeld \#17) verwys ek na my eie kommentaar aan die einde van die vertaling.

4. Die werke van Kant waarna heelwat verwys word, word soos volg afgekort:

$K r V \quad K$ Kritik der reinen Vernunft

$K \rho \vee \quad K r i t i k$ der praktischen Vernunft

MdS Metaphysik der Sitten

Fundering Grundlegung zur Metaphysik der Sitten

P S Dreyer

(Professor Honorêr, Universiteit van Pretoria). 